\title{
Ecological requirements and relative impact of threats affecting the Austral Rail Rallus antarcticus: monitoring methodology considerations for an imperative conservation status re-evaluation
}

\author{
ANDRÉS DE MIGUEL, LAURA FASOLA, IGNACIO ROESLER, LUCÍA MARTIN, \\ NATALIA COSSA and EMILIA GIUSTI
}

\begin{abstract}
Summary
Since its rediscovery in 1998, two major threats have been mentioned for the enigmatic Austral Rail Rallus antarcticus: cattle management by burning grass and rushes and predation by American mink Neovison vison. Added to the lack of a protocol to monitor this secretive bird, ever-growing threats make it necessary to study its global situation in depth to take accurate and urgent management decisions. We firstly studied how threats to the Austral Rail currently impact their occupancy and relative density (RD) at a wetland scale and habitat features associated with its presence at survey site scale inside wetlands in Santa Cruz province, Argentina. We additionally developed a monitoring protocol to detect the rail effectively and promptly by studying responses to playback with two different vocalisations at different times of the day and season. Both threats evaluated were negatively related to occupancy and RD of the Austral Rail, especially mink presence appearing to have an additive effect. We propose American mink control as crucial for Austral Rail conservation, while it would also be necessary to conserve a portion of wetlands exempt from burning and cattle presence. At survey sites, its presence was positively related with c.I-1.5 $\mathrm{m}$ tall rushes, whilst rails avoided low- density rush areas that resulted after management of rushes with fire to create pasture. To detect rails, both vocalisations can be confidently used at any time of the day and season. The poor knowledge about species ecology, mismanagement of vegetation in wetlands, expansion of American mink in Patagonia, construction on two dams in the Santa Cruz river basin, added to the already modified humidity conditions due to global climate change, force us to suggest that the Austral Rail should be considered as globally 'Endangered' (EN), to ensure the consideration of the species in management decisions.
\end{abstract}

\section{Introduction}

Rails are one of the most endangered groups of birds in the world, with $20 \%$ of them (33 species) globally threatened with extinction (BirdLife International 2018). Habitat loss and invasive species (mostly mammals) are rapidly reducing their populations and many rails are becoming endangered before our knowledge enables effective conservation measures to be implemented (BirdLife International 2018). In Argentina, two of the 26 species present are threatened, the Austral Rail Rallus antarcticus and the Dot-winged Crake Porzana spiloptera, both 'Vulnerable' (VU), 
whilst a third one, Speckled Rail Coturnicops notatus, is considered as 'Least Concern' (LC), but may approach the thresholds for 'Vulnerable' (BirdLife International 2018).

Austral Rail is a poorly known and enigmatic inhabitant of some of the scattered wetlands of the desert area of Austral Patagonia, in southernmost South America (Taylor et al. 2018). There is a lack of historical information about the species. In almost a century, there were only five known records (two of them doubtful) and after 39 years without documented sightings it was classified as 'Endangered/Extinct' (EN/EX) (Collar et al. 1992). It was re-discovered in 1998 in Santa Cruz province, Argentina (Mazar Barnett et al. 1998) and classified as 'Vulnerable' in 2000 (BirdLife International 2018), 'Endangered' at a national level in Argentina (AA \& MAyDS 2017) and as 'Insufficient data' at a national level in Chile (Ministerio del Medio Ambiente 2018). Later on, during an extensive survey using playback technique, the species was found in at least 18 additional localities. The survey provided novel data on distribution and habitat, whilst its vocalisations also were recorded for the first time during its rediscovery (Mazar Barnett et al. 2014). The core of the population occurs in Santa Cruz province, Argentina and Magallanes Region, Chile (Mazar Barnett et al. 2014), including some records in protected areas in Argentina (Los Glaciares National Park (NP), Bosques Petrificados NP and Chile (Torres del Paine NP, Pali Aike NP).

Added to the lack of protection of the Austral Rail population, there are two major plausible threats: cattle management and alien predators (Mazar Barnett et al. 2014). Wetlands in Patagonia have been heavily used, although poorly managed, by ranchers to support their cattle and sheep. In some cases, there is a reduction in the extent of marshy habitat due to burning and harvesting in early spring, to encourage strong growth of grass shoots to feed cattle (Fjeldså 1988). The American mink Neovison vison is an invasive semi-aquatic generalist predator (Fasola et al. 2010, Fasola and Roesler 2018) that is expanding its distribution in Santa Cruz province, Argentina (Fasola and Valenzuela 2014, Fasola and Roesler 2016). It is strongly affecting other threatened birds in the region, such as the Hooded Grebe Podiceps gallardoi (Roesler et al. 2012a, 2012b) and possibly the Torrent Duck Merganetta armata (Cerón and Trejo 2012). In Europe, it is known to have a negative impact on populations of the Water Rail Rallus aquaticus (Bonesi and Palazon 2007). In Argentina, its increasing distribution was related to the concomitant decline of the Austral Rail (Roesler et al. 2014) and it was considered a possible cause of its extinction in several parts of northern Patagonia (Fraga 2000).

Many habitat features can determine the presence of Rallidae, such as the height and density of rushes (Roach and Barrett 2015), water depth, vegetation coverage and food availability (Baschuk 2012), whilst aspects related to human activities, such as cattle (Richmond et al. 2012) and alien species (Donlan et al. 2007) may also play an important role. We studied the ecological requirements of Austral Rail in wetlands of Santa Cruz Province, Argentina, at two scales. At each wetland, we associated the occupancy and relative density of the Austral Rail with the cattle management type and American mink presence. Within each wetland, we associated rail presence at different location with vegetation characteristics and the accompanying bird community, aiming to find out key habitat features that favour the presence of the Austral Rail.

As well as knowing where to find the Austral Rail, it is also useful to know how to detect it. Most rails behave secretively and inhabit dense flooded vegetation and are therefore difficult to detect (Taylor and Van Perlo 1998). Playback is widely used to determine population abundance and habitat requirements, as with the globally 'Endangered' Junín Rail Laterallus tuerosi (Dinesen 2017) at Junín Lake, or studies at community level such as habitat segregation between Rufous-sided Crake L. melanophaius and Red-and-white Crake L. leucopyrrhus in Argentina (Depino and Areta 2017).

With the aim of developing a monitoring protocol that enables effective and rapid detection of the Austral Rail using playback, we assessed the ability of detection and latency (time lag until first response) of two vocalisations of the rail, testing at different times of the day and different periods of the reproductive season. 


\section{Methods}

\section{Study area}

The study was conducted in central and north-western Santa Cruz province, Argentina, between December 2015 and April 2016. The dominant habitat is the Patagonian steppe, a semidesert with annual precipitation below $250 \mathrm{~mm}$. The Austral Rail inhabits marshy oases dominated by rushes Schoenoplectus californicus, and associated with a permanent shallow water body, a large river, a creek or a lake (Mazar Barnett et al. 2014). However, wetlands are scarce and scattered in the area and represent only 1.13\% of the province's area (Malvárez and Bó 2004). These rushes typically possess a dense layer of $30-40 \mathrm{~cm}$ of dead rushes, bent over to form a 'mattress', nourished annually by the dead plants of the previous season (Mazar Barnett et al. 2014), where the rails are known to breed (Jaramillo 2003, Moroni and Salvador 2016, Matus et al. 2017).

We worked at five wetlands located on different ranches and associated with two of the principal river basins in Santa Cruz province (Figure I). "San Carlos" $\left(46^{\circ} 33^{\prime} \mathrm{S}, 70^{\circ} 38^{\prime} \mathrm{W}\right)$; "La Madrugada" $\left(47^{\circ} \mathrm{O}^{\prime} \mathrm{S}, 70^{\circ} 29^{\prime} \mathrm{W}\right)$, "Las Buitreras" ( $\left.47^{\circ} \mathrm{O}^{\prime} \mathrm{S}, 70^{\circ} 30^{\prime} \mathrm{W}\right)$ and "El Unco" ( $\left.47^{\circ} 15^{\prime} \mathrm{S}, 70^{\circ} 51^{\prime} \mathrm{W}\right)$

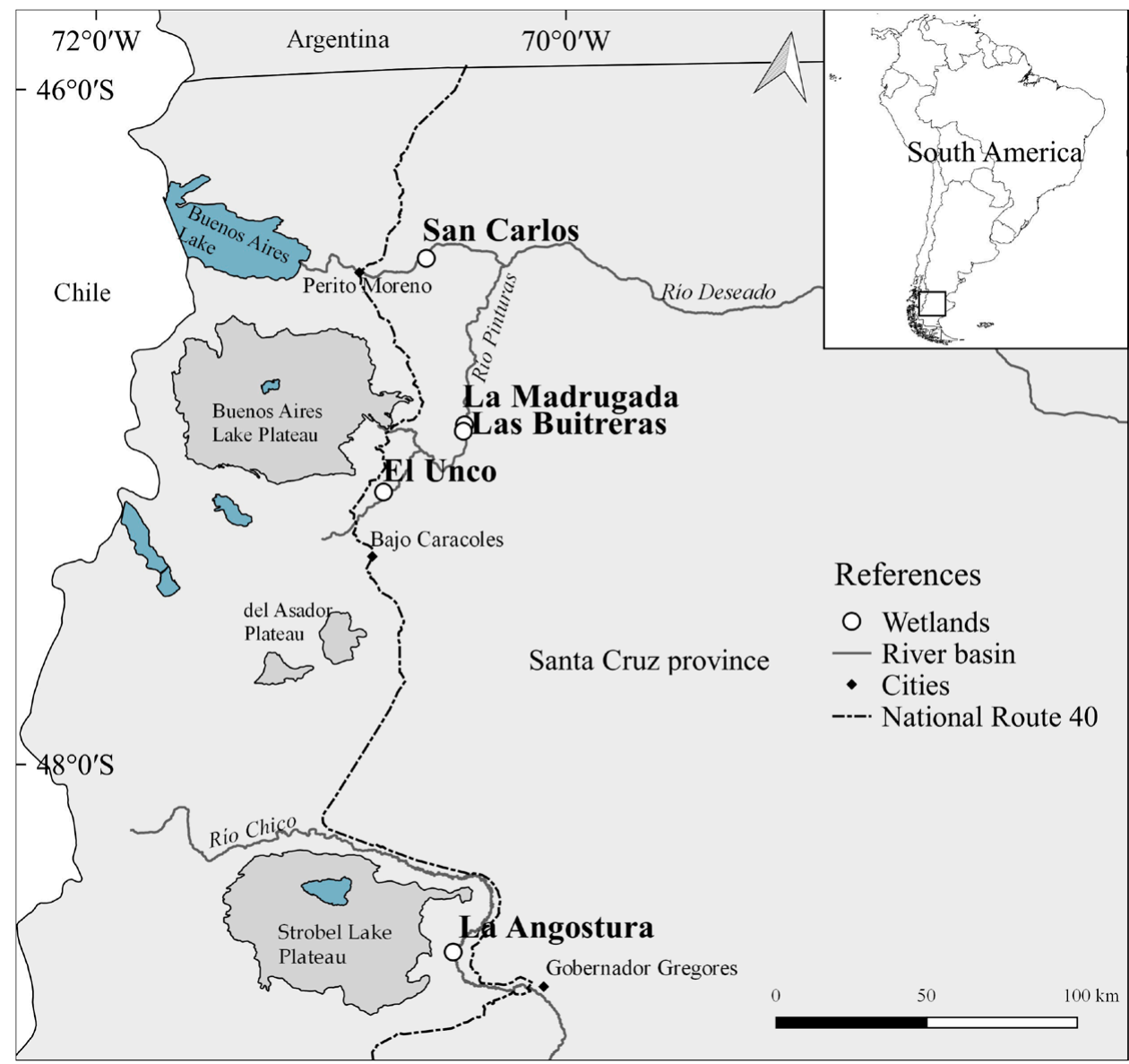

Figure 1 . Wetlands where the study was carried out, located on five ranches associated with two of the principal river basins of Santa Cruz province, Argentina: San Carlos, La Madrugada, Las Buitreras and El Unco correspond to Río Deseado basin, while La Angostura belongs to the Río Chico basin. 
correspond to Río Deseado basin, while "La Angostura" ( $48^{\circ} 28^{\prime} \mathrm{S}, 70^{\circ} 38^{\prime} \mathrm{W}$ ) belongs to the Río Chico basin. At each locality, we distributed 1o survey sites along the edge of the wetland (except for La Angostura, where five sites where surveyed in a small selected plot without cattle), separated by at least $100 \mathrm{~m}$ to avoid double-counting. We considered a detection/hearing radius of approximately $50 \mathrm{~m}$ for each survey site. The surveys were conducted during two periods of the reproductive season: December 2015, assumed to be part of the breeding stage (hereafter 'December'), and late March-early April 2016, assumed to be part of the post-breeding stage (hereafter 'March').

\section{Impact of threats}

We analysed the occupancy and relative density (RD) of Austral Rail in relation to the threats. At each wetland, we recorded the occurrence and intensity of the threats: 'cattle management' and 'American mink presence'. We considered two categories for cattle management methods: ' ++ ' for wetlands where rushes had been burned in the previous spring or wetlands where cattle were present during surveys; and '--' for wetlands with un-burned rushes or without cattle at the time of the surveys. We defined three categories for American mink intensity: ' ++ ' for presence of scats and/or footprints along a transect indicating recent use; ' +- ' for past presence confirmed by previous studies/surveys or confirmed through interviews with farmers; and '--' when neither scats nor footprints were found on the transect and no confirmed past presence. We estimated occupancy corrected by imperfect detection using occupancy models, whilst RD was estimated from $R D=n /$ sites, where $n=$ the maximum number of individuals detected in all of the four visits, and sites = number of survey sites in each wetland.

\section{Ecological requirements}

To relate Austral Rail presence to habitat characteristics at each survey site, we defined a set of variables. Rush height was categorised as 'High' (> $2 \mathrm{~m}$ ); 'Medium' (I-2 m); and 'Low' (<I m). Rush density categories were 'High' (presence of dry rush beds of previous season), and 'Low' (absence of dry rush beds). We also recorded bird community richness of the rushes, which included: Wren-like Rushbird Phleocryptes melanops, Many-colored Rush Tyrant Tachuris rubrigastra, Grass Wren Cistothorus platensis, Yellow-winged Blackbird Agelasticus thilius, Spectacled Tyrant Hymenops perspicillatus, Plumbeous Rail Pardirallus sanguinolentus, Cinereous Harrier Circus cinereus, ducks (Anatidae spp.) and coots (Fulica spp.). Species richness was used as an indirect indicator of habitat complexity (hereafter 'Bird Community'). Austral Rail presence at each survey site was assessed using playback broadcasting of two vocalisations over a period of Io minutes (five minutes for each vocalisation, as explained below). We then looked for changes in the associations of rail presence and habitat variables between December and March using a GLM with Bernoulli error distribution.

\section{Improved monitoring protocol}

We surveyed each survey site twice a day: three hours after dawn (hereafter 'dawn') and two hours before dusk (hereafter 'dusk'). We considered each combination of December/March and dawn/dusk as a visit. We analysed the influence of the vocalisation used during playback, the time of day, and the breeding season period in the probability of detection and time lag until response (latency).

During each visit, we broadcast two vocalisations of the Austral Rail: a 'duet', in which two individuals call simultaneously, and a 'song' in which one individual calls repeatedly (Mazar Barnett et al. 1998). These vocalisations were selected as being the most frequently emitted by rails, so we expected more responses than using others. At each survey site, we selected randomly 
one vocalisation and broadcast it for one minute, then allowing a five-minute detection period. We always broadcast the vocalisations controlling for volume, distance from the rushes, equipment and wind speed (always below $20 \mathrm{~km} / \mathrm{h}$ ). We recorded detection (yes/no, only for vocal responses), time until the first response (in seconds) and the number of different individuals detected: (a response coming from the same direction and at the same intensity was considered the same individual or couple).

To develop the monitoring protocol we carried out two analyses. We estimated detection probability associated with each vocalisation and period of breeding season using occupancy models (MacKenzie 2006). Given that we did not find major changes in survey sites measured for occupancy, we assume survey sites were closed to immigration and followed a single-species and single-season design. The competing models in the detection module included the different combinations of the variables: 'voice' ('duet' or 'song'), period of the 'Season' (December or March) and the interaction of the two. For the occupancy model, the competing models included the identity of the "wetland' ("El Unco", "Las Buitreras", "La Madrugada", and "La Angostura"; "San Carlos" was excluded because no rails were detected there). We used the AIC criterion to fit both modules, the detection module in first place. Finally we used the selected model to estimate the detection probability for each vocalisation and period of the season using 'logit' link function.

To test the effect of time of day ('Day'), period of season ('Season'), vocalisations ('Voice') and the interactions Voice*Season and Voice* Day, on the 'Latency', we used generalised linear models (GLM) with Gamma error distribution and the 'log' link function. We used only those cases where at least one individual was detected $(n=65)$. To estimate the expected latency (sec) we used ' $\log ^{\prime}$ link function running an average model using the selected models.

All statistical analyses were carried out using $\mathrm{R}$ software, version 3.I (R Core Team 2016). The 'unmarked' $R$ package was used for occupancy modelling (Fiske and Chandler 2011). 'MuMIn' R package (Burnham and Anderson 2003) was used for model selection. For Multi-Model Inference we selected models by AIC criterion and those with the highest weight $\left(w_{\mathrm{i}}\right)$.

\section{Results}

\section{Impact of threats}

American mink presence was confirmed in three of the five wetlands. One (San Carlos) was confirmed by recording fresh scats at two dens; two (Las Buitreras and La Madrugada) were known to be occupied by mink from a previous study (Fasola and Roesler 2018) and by interviews with ranchers who declared having hunted one. We did not find fresh mink signs at El Unco or La Angostura, nor did the ranchers mention having seen mink in previous years.

There was no cattle management of the rush beds at El Unco, San Carlos or La Angostura (at least not in the small selected plot). Even when there was sheep production in the first two cases, the impact was located along the edge of the rush bed but not inside it. In Las Buitreras and La Madrugada, rushes were burned the previous winter and cattle were found feeding inside the rush bed. We found the highest rail occupancy and density at El Unco and La Angostura, the lowest at Las Buitreras and La Madrugada, whilst we did not detect rails in San Carlos at all (Table 1 ).

\section{Ecological requirements}

The best model for December included only 'Height' ( $w_{\mathrm{i}}=0.32$; Table 2); only Medium Height maximised the probability of rail presence (C.I. $\alpha=0.05=0.39 ; 5.65, P<0.05 ;$ Table 2 ), whereas in March there were three candidate models with similar weight that included all. 
Table 1. Association between occupancy and relative density (respective values) of the Austral Rail and wetland management: Cattle Management Methods (-- without previous burning and no cattle in rushes during surveys; ++ previous burning and cattle in rushes during surveys) and American mink presence (-- no signs found during surveys and no previous presence mentioned by local farmers; -+ no signs found while surveys but previous presence mentioned by local farmers; ++ signs found during surveys and previous presence mentioned by local farmers). N/D indicates combinations of management that were not surveyed.

\begin{tabular}{|c|c|c|c|}
\hline & & \multicolumn{2}{|c|}{ Cattle Management Method } \\
\hline & & -- & ++ \\
\hline & -- & $\begin{array}{l}\text { El Unco 0.99; } 3.4 \\
\text { La Angostura 0.99; } 1.8\end{array}$ & $\mathrm{~N} / \mathrm{D}$ \\
\hline \multirow[t]{2}{*}{ American mink } & -+ & $\mathrm{N} / \mathrm{D}$ & $\begin{array}{l}\text { La Madrugada 0.46; } 1.0 \\
\text { Las Buitreras 0.32; } 0.7\end{array}$ \\
\hline & ++ & San Carlos o.oo; 0.0 & $\mathrm{N} / \mathrm{D}$ \\
\hline
\end{tabular}

We built an average model with them that detected a negative association between low rush density and rail presence (C.I. $\alpha=0.05=-5.61 ;-0.11, P<0.05$ ). We found no differences between High and Medium Height rushes (Tukey, $P=0.5$ ). We found a negative but not significant association between high size and rail presence, and a positive, but not significant, association between medium size and rail presence. We did not find a significant effect of bird community on Austral Rail presence in either of the periods considered.

\section{Improved monitoring protocol}

We included 30 detection histories in the analysis of occupancy. The best ranked model included the variable 'Voice' for the detection module (Table 3 a) and wetland identity for the occupancy module (Table $3 \mathrm{~b}$ ). Based on this model, the vocalisation 'song' was 1.5 times more effective than 'duet' in detecting rails when used as first call (probability of detection 0.9I vs. 0.62 , respectively).

For latency analysis, the first two models accounted for almost 0.6 of the relative weight and were selected. Combined, they included 'Voice' and 'Season', but not their interaction (Table 4). In the averaged model, the predicted latency for 'Song' (105 s, expected range: 50-222 s) was significantly higher than for 'Duet' (44 s, expected range: 31-62 s, $P<0.001$ ); we found no differences between seasons $(Z=1.3, P=0.19$; Table 5$)$.

Table 2. Model selection summary of 17 candidate models explaining Austral Rail presence in survey sites inside Santa Cruz province's wetlands, Argentina, in December 2015 (a) and in March 2016 (b).

\begin{tabular}{lllll}
\hline \multicolumn{2}{l}{ December } & & & \\
\hline Model & df & AIC & $\Delta$ AIC & $w_{\text {i }}$ \\
\hline Height ${ }^{*}$ & 3 & 47.2 & 0.00 & 0.32 \\
Null & 1 & 48.3 & 1.10 & 0.19 \\
Height + Density & 4 & 48.4 & 1.16 & 0.18 \\
Height + Density + Bird Community & 5 & 51.1 & 3.86 & 0.05 \\
\hline & March & & & \\
\hline Model & df & AIC & AIC & 0.32 \\
\hline Density + Bird Community * & 3 & 30.7 & 0.00 & 0.24 \\
Density & 2 & 31.2 & 0.57 & 0.22 \\
Height + Density + Bird Community & 4 & 31.4 & 0.75 & 0.02 \\
Null & 1 & 35.8 & 5.16 & \\
\hline
\end{tabular}


Table 3. Model selection summary of five candidate models explaining the detection (a) and two candidate models explaining the occupancy (b) of the Austral Rail in Santa Cruz province wetlands, Argentina. *indicates selected models with an AIC and weight criteria.

\begin{tabular}{|c|c|c|c|c|}
\hline \multicolumn{5}{|c|}{ a. Detection module } \\
\hline Model & $\mathrm{k}$ & $\mathrm{AICc}$ & $\triangle \mathrm{AICc}$ & $w_{\mathrm{i}}$ \\
\hline Voice $^{*}$ & 6 & 63.01 & 0.00 & 0.39 \\
\hline Voice + Season + Voice:Season & 8 & 36.97 & 0.95 & 0.24 \\
\hline Null & 5 & 64.86 & 1.85 & 0.16 \\
\hline Voice + Season & 7 & 64.97 & 1.96 & 0.15 \\
\hline Season & 6 & 66.77 & 3.76 & 0.06 \\
\hline \multicolumn{5}{|c|}{ b. Occupancy module } \\
\hline Model & $\mathrm{k}$ & AIC & $\triangle \mathrm{AICc}$ & $w_{\mathrm{i}}$ \\
\hline Voice + Wetland * & 6 & 63.01 & 0.00 & 0.99 \\
\hline Voice + Null & 3 & 73.03 & 10.02 & 0.01 \\
\hline
\end{tabular}

\section{Discussion}

\section{Threats as determinants of Austral Rail wetland occupancy and density}

Managed wetlands invaded by the American mink do not support Austral Rail populations. The threats evaluated in this work were negatively related to the occupancy and density of the Austral Rail. In some cases, the American mink appears to have a stronger impact on the Austral Rail population than cattle management. There is an abundant population of mink in San Carlos (Fasola unpubl. data.), and despite the favourable habitat characteristics of its rushes, we could not detect any rails. However, we do not dismiss the possibility of the presence of rails in some isolated spots of this wetland, as has been the case for at least one other area of the same basin (Río Deseado basin) where occupancy seems to be occasional (Mazar Barnett et al. 2014). Macpherson and Bright (2010) mentioned that inside rush beds in the UK, radio-tagged American mink used mostly open and easy to navigate channels to feed, avoiding some compact rush beds that in turn serve as refuges for native species. We think that this can be extrapolated to some wetlands occupied by the Austral Rail, especially where cattle are absent and cannot create these channels. Further studies will deepen the understanding of this possible facilitation effect between cattle and mink. In Las Buitreras and La Madrugada, mink density is lower than in San Carlos, and wetland management involves annual burns that drive profound changes in rush path structure. There, we found a low proportion of occupied survey sites and low density. Even when regrowth might allow colonisation by rails, the number of individuals found is lower than the number found in wetlands without burning management. In the last case, El Unco and La Angostura, without cattle management and without mink, presented the highest values of occupancy and density. Furthermore, El Unco is one of the most important localities for Austral Rail conservation, with a population reaching over 30 individuals. Mazar Barnett et al. (2014) reported only two localities with populations over 30 individuals, El Zurdo

Table 4. Model selection summary of four candidate models explaining the latency (sec) of responses to the playback of the Austral Rail in Santa Cruz province wetlands, Argentina. *indicates selected models with an AIC and weight criteria.

\begin{tabular}{lllll}
\hline Model & df & AIC & $\Delta$ AIC & $w_{\text {i }}$ \\
\hline Voice $^{*}$ & 3 & 686.4 & 0.00 & 0.352 \\
Voice + Season * $^{*}$ Voice + Season + Voice:Season + Voice: Day & 4 & 687.1 & 0.79 & 0.237 \\
Null & 7 & 639.4 & 7.08 & 0.010 \\
\hline
\end{tabular}


Table 5. Terms of the average model built with selected models of latency analysis which included variables 'Voice' and 'Season'. * indicates terms which influenced significantly in the model.

\begin{tabular}{llllrc}
\hline Term & Estimator & $\mathrm{CI}_{\alpha=0.05}$ & SE Adjust & $\mathrm{Z}$ & $P$-value \\
\hline Intercept & 3.78 & $(3.44 ; 4.13)$ & 0.18 & 21.3 & $<0.001^{*}$ \\
Voice Song & 0.87 & $(0.47 ; 1.27)$ & 0.21 & 4.2 & $<0.001^{*}$ \\
Season March & -0.26 & $(-0.66 ; 0.13)$ & 0.20 & 1.3 & 0.19 \\
\hline
\end{tabular}

$\left(52^{\circ} \mathrm{Oo} \mathrm{S}^{\prime} 71^{\circ} 14^{\prime} \mathrm{W}, 34\right.$ individuals) and La Angostura ( 35 individuals). In future, the inclusion of more wetlands in the study will allow for a better understanding of the separate and combined effect of the different threats.

\section{Optimal habitat and Austral Rail presence within a wetland}

The wetlands that Austral Rail inhabits are complex mosaics of rushes and wet grassland. In many cases, the rushes are fragmented into patches with different characteristics, and even when they are continuous, they show some level of heterogeneity. High vegetation had been positively related with rallid presence such as Virginia Rail Rallus limicola and Sora Porzana carolina (Johnson and Dinsmore 1986), King Rail R. elegans (Darrah and Krementz 2011) and Mangrove Rail R. longirostris (Conway et al. 1993). We found a similar pattern for the Austral Rail. Presence of the species at a survey site was positively associated with medium height rushes (c.1-2 m). Tall vegetation could be favoured as an anti-aerial predator strategy. The lack of association with the higher class may be due to a low number of sampling points with rushes of this height. This is an aspect that deserves to be studied in-depth in the future to develop better management recommendations.

A consequence of wetland management with fire is the reduction in rush density. Survey sites with low-density rushes were common at Las Buitreras and La Madrugada. Thus, the effect of burns on vegetation at the survey site scale seems to explain the low occupancy/density pattern found at the wetland scale. Also, the accumulation of dry rushes from the previous season, sometimes mixed with grass at the base of the rushes, could be important for nest construction and concealment, as has been observed in the few known recent breeding events (Matus et al. 2017, Moroni and Salvador 2016, AdM pers. obs.).

We did not find a relationship between bird community richness and Austral Rail presence. We considered this variable as a proxy of the complexity of the vegetation at each survey site. Even when we did not find any association, we think that the variable should be refined before it is dismissed. Variables like water depth (Darrah \& Krementz 2011), vegetation cover and food availability (Baschuk 2012) are features highly influential for other rallidae, which we did not evaluate.

\section{Monitoring protocol for further studies}

Developing a monitoring protocol requires the analysis of many factors simultaneously. Information on how detection is affected by the applied methodology (e.g. which vocalisation broadcast and when to do it) is as important as to how it is applied (e.g. how long to wait for a response), because it can lead to better results with low survey costs.

The lack of influence of the period of breeding season in detection probability and the lack of influence of this factor and time of day in latency lead to the possibility of extending Austral Rail monitoring to the whole summer season, instead of restricting surveys to a particular time of the season and day. These results suppose low survey cost advantages when long distances between sites and hard climatic conditions (e.g. strong winds) usually delay fieldwork, even more in Patagonia. However, we did not test the influence of the time of day on detection probability, and we surveyed neither in spring nor late autumn. These aspects will be developed in further studies to refine the protocol and explore how survey methodologies should be applied to extend monitoring and cover wider areas. 
We found a trend for the 'song' to be 1.5 times more effective in detecting Austral Rail than the 'duet' in a first broadcast and that the probability of detection was almost the maximum. However, latency analysis revealed that we needed on average to spend 2.4 times more time to get an answer with this vocalisation than with the 'duet'. Therefore, there are different possibilities when using playback to detect the species. Both vocalisations can be confidently used to detect the species. The 'song' vocalisation could be used once with a waiting time of almost four minutes before confirming the absence of the species. If the available vocalisation is 'duet', then it should be broadcast at least twice with a waiting time of 62 seconds after each call before labelling the site as negative for rail presence. However, when both vocalisations are available, then the best choice in terms of efficacy and accuracy would be to broadcast them in the order duet-duet-song with the respective waiting times in between. The benefit of having a vocalisation (or combination) with high detection probability and low latency is to survey large areas of rushes taking advantage of the optimum survey hours of the day (dusk or dawn). Results of latency and detection probability may be different during early to mid-spring, at the beginning of the breeding season, so it would be interesting to evaluate seasonal variations.

\section{Conservation of the Austral Rail}

The negative impact of the American mink on native bird populations is globally accepted (Bonesi and Palazon 2007). In Patagonia, its effect on the Austral Rail has been proposed before, and our study reinforces the hypothesis of the role of mink as a limiting factor on Austral Rail populations. We consider that control of American mink is crucial for Austral Rail conservation. Firstly, controlling mink at wetlands occupied by Austral Rails could have a starter effect in the recovery of rail populations. Secondly, preventing mink arrival in those areas with rails that are currently free of mink is fundamental. Given that ongoing programmes for American mink control are succeeding in reducing mink impact on another endangered species in Austral Patagonia (Fasola and Roesler 2017), expansion of these efforts is urgently needed.

We also found that wetlands managed for cattle rearing could not support large numbers of rails. More importantly, grazing can have a severe impact on Austral Rail breeding by eliminating most of the rush beds where rails build their nests. Rails appear to prefer at least $1-\mathrm{m}$ tall rush patches, maybe to hide from aerial predation by raptors, to short rushes that result when cattle feed on them. We demonstrate that rails avoid inner survey sites with low density rushes, favouring those with a matrix of dry rushes from the previous season and sometimes a dense matrix of grass in the base of the rushes where rails nest (Jaramillo et al. 2003, Matus et al. 2017, AdM pers. obs.). Landowners should be encouraged to preserve wetland patches during programmed burns to keep a proportion of wetland favourable for the reproduction of the rail. A good example of cattle management and habitat protection for the Austral Rail is in La Angostura. On this farm, a portion of the wetland is managed to support rails and other birds for the benefit of bird watching tourism, which is a profitable and alternative economic activity for the owners.

Recent increasing monitoring efforts, mostly during the breeding season, have detected Austral Rail populations in new localities such as El Unco, which has proved to be one of the most important wetlands for the species. The other most important populations in terms of abundance are also in Santa Cruz province, including key sites around Lago Argentino such as 'El Sosiego', with one of the highest populations, and near Punta Banderas, Parque Nacional Los Glaciares where two nests where found in spring 2015 (Moroni and Salvador 2016). These important sites would be drastically flooded by the completion of two dams that are being constructed on the Río Santa Cruz, affecting the natural outflow of Lago Argentino. Simultaneously, global climatic change is already modifying the humidity conditions of Austral Patagonia, drying up wetlands (Ruzzante and Rabassa 2011).

The new information presented in this study suggests that the Austral Rail has important, growing and unattended threats and that its conservation depends on action and management. The lack of management policies for the threats, together with the potential impact of the 
hydroelectric dams along the Río Santa Cruz basin and global climate change, force us to strongly recommend a re-evaluation of the global conservation status. This re-evaluation should also consider the low population size, the small number of localities where the species is confirmed and where breeding is known to occur, the low number of sites with favourable habitat and the growing threats. The current status of the species seems no longer congruent with its real situation and an upgrade to globally 'Endangered' (EN) might be more appropriate. The classification suggested will be relevant for the consideration of the species in government and management decisions.

\section{Acknowledgements}

We thank members and volunteers of 'Proyecto Macá Tobiano' who actively collaborated in the fieldwork: J. Klavins, P. Pascoe, S. Briones, P. Buchanan, M. Deming, P. Hernández, L. Romagnoli and P. Chiesa. We thank owners and personnel of El Unco, San Carlos, La Madrugada, Las Buitreras and La Angostura Estancias for allowing us conducting fieldwork on their land and their hospitality (especially to the family Kusanovic from La Angostura and Juan Garitaonandia form San Carlos). We thank members of the Laboratorio de Ecología y Comportamiento Animal (FCEyN, UBA) for advice and comments on previous versions of this manuscript, M. Codesido, G. Cueto, and R. Cavia for their valuable contributions. We finally thank the two reviewers and the lead editor of BCI for the improvement of the manuscript. This is scientific publication \#16 of the Proyecto Macá Tobiano. The work was supported by Proyecto Macá Tobiano (Hooded Grebe Project, HGP), an association between Aves Argentinas/AOP and Asociación Ambiente Sur, as a part of Aves Argentinas/AOP Patagonian Program. The Juan Mazar Barnett Biological Station, is supported by Fundación Flora y Fauna Argentina. Patagonia Inc., BirdLife International (Preventing Extinctions Program) contributed donations to Patagonia Program. Idea Wild and Birder's Exchange donated equipment. Toyota Argentina S.A. provided 4x4 vehicles for fieldwork. Servicios Públicos Sociedad del Estado in Santa Cruz, provided fuel. Laura Fasola and Ignacio Roesler are Fellow Researchers of CONICET.

\section{References}

AA \& MAyDS (2017) Categorización de las aves de la Argentina (2015). C. A. Buenos Aires, Argentina: Informe del Ministerio de Ambiente y Desarrollo Sustentable de la Nación y de Aves Argentinas, edición electrónica.

Baschuk, M. S., Koper, N., Wrubleski, D. A. and Goldsborough, G. (2012) Effects of water depth, cover and food resources on habitat use of marsh birds and waterfowl in boreal wetlands of Manitoba, Canada. Waterbirds 35: 44-55.

BirdLife International (2018) Rallus antarcticus. IUCN Red List for birds. http://www.birdlife. org (accessed on 9 March 2018).

Bonesi, L. and Palazon, S. (2007) The American mink in Europe: status, impacts and control. Biol. Conserv. 134: 470-483.

Burnham, K. P. and Anderson, D. R. (2003) Model selection and multimodel inference: a practical information-theoretic approach.
New York, USA: Springer Science \& Business Media.

Cerón, G. and Trejo, A. (2012) Torrent Duck Merganetta armata population trend in northwestern Patagonia, Argentina. Ornitol. Neotrop. 23: 407-415.

Collar, N. J., Gonzaga, L. P., Krabbe, N., Madroño Nieto, A., Naranjo, L. G. et-al (1992) Threatened birds of the Americas: the ICBP/IUCN Red Data Book. Cambridge, UK: International Council for Bird Preservation.

Conway, C. J., Eddleman, W. R., Anderson, S. H. and Hanebury, L. R. (1993) Seasonal changes in Yuma clapper rail vocalization rate and habitat use. J. Wildl. Manage. 282-290.

Darrah, A. J. and Krementz, D. G. (2009). Distribution and habitat use of King rails in the Illinois and Upper Mississippi River Valleys. J. Wildl. Manage. 73: 1380-1386.

Depino, E. A. and Areta, J. I. (2017) Ecological segregation and vocal interactions in two 
sympatric Laterallus crakes. J. Ornithol. 152: 431-441.

Dinesen, L., Chamorro, A., Fjeldså, J. and Aucca, C. (2017) Distribution and habitat description of Junín Rail Laterallus tuerosi, Andean Peru. Bird Conserv. Internatn. 1-10.

Donlan, C. J., Campbell, K., Cabrera, W., Lavoie, C., Carrion, V. and Cruz, F. (2007) Recovery of the Galápagos Rail Laterallus spilonotus following the removal of invasive mammals. Biol. Conserv. 138: 520-524.

Fasola, L., Muzio, J., Chehébar, C., Cassini, M. and Macdonald, D. W. (2010) Range expansion and prey use of American mink in Argentinean Patagonia: dilemmas for conservation. Eur. J. Wildl. Res. 57: 283-294.

Fasola, L.and Roesler,I.(2016) Invasive predator control program in Austral Patagonia for endangered bird conservation. Eur. J. Wildl. Res. 62: 601-608.

Fasola, L. and Roesler, I. (2018) A familiar face with a novel behaviour raises challenges for conservation: American mink in arid Patagonia and a critically endangered bird. Biol. Conserv. 218: 217-222.

Fasola, L. and Valenzuela, A. E. (2014) Invasive carnivores in Patagonia: defining priorities for their management using the American mink (Neovison vison) as a case study. Ecología Austral 24: 173-182.

Fiske, I. and Chandler, R. (2011) unmarked: An R package for fitting hierarchical models of wildlife occurrence and abundance. J. Statist. Softw. 43: 1-23.

Fjeldså, J. (1988) Status of birds of steppe habitats of the Andean zone and Patagonia. ICBP Technical Publication 1: 81-95.

Fraga, R. M. (2000) Introduced feral mink Mustela vison in Patagonia: a plausible cause of populations declines in the Austral Rail Rallus antarcticus? Cotinga 13: 71-72.

Jaramillo, A., Aguirre, J., Imberti, S. and Matus Navarro, R. J. (2003) Hallazgo de dos nidos de Pidén Austral Rallus antarcticus en el Parque Nacional Torres del Paine, VII Neotropical Ornithological Congress, Termas de Puyehue, Chile 5-11 October.

Johnson, R. R. and Dinsmore, J. J. (1986) Habitat use by breeding Virginia rails and Soras. J. Wildl. Manage. 387-392.

MacKenzie, D. I., Nichols, J. D., Royle, J. A., Pollock, K. H., Bailey, L. L. and Hines, J. K.
(2006) Occupancy estimation and modeling: Inferring patterns and dynamics of species occurrence. London, UK: Elsevier.

Macpherson, J. L. and Bright, P. W. (2010) Movements of radio-tracked American mink (Neovison vison) in extensive wetland in the UK, and the implications for threatened prey species such as the water vole (Arvicola amphibius). Eur. J. Wildl. Res. 56: 855-859.

Malvárez, A. I. and Bó, R. F. (2004) Documentos del curso taller "Bases ecológicas para la clasificación e inventario de humedales en Argentina" (Vol. 30). Buenos Aires, Argentina: Ana Inés Malvárez editora.

Matus, R., Aguirre, J., Jaramillo, A. and Imberti, S. (2017) Nidificación del pidén austral (Rallus antarcticus) en el Parque Nacional Torres del Paine, Magallanes, Chile austral. Revista Chilena de Ornitología 23: 43-47.

Mazar Barnett, J., della Seta, M., Imberti, S. and Pugnali, G. (1998) Notes on the rediscovery of the Austral Rail Rallus antarcticus in Santa Cruz, Argentina. Cotinga 10: 96-101.

Mazar Barnett, J., Imberti, S. and Roesler, I. (2014) Distribution and habitat use of the Austral Rail Rallus antarcticus and perspectives on its conservation. Bird Conserv. Internatn. 24: 114-125.

Ministerio del Medio Ambiente (2018) Rallus antarcticus. Inventario nacional de especies de Chile. http://www.especies.mma.gob.cl (accessed on 12 March 2018).

Moroni, M. and Salvador, S. (2016) Descripción del nido, huevo y pichón de la Gallineta Chica Rallus antarcticus. Historia Natural 6: 5-12.

$\mathrm{R}$ Core Team (2016) R: A language and environment for statistical computing. Vienna, Austria: R Foundation for Statistical Computing. http://www.r-project.org.

Richmond, O. M., Tecklin, J. and Beissinger, S. R. (2012) Impact of cattle grazing on the occupancy of a cryptic, threatened rail. Ecol. Applic. 22: 1655-664.

Roach, N. S. and Barrett, K. (2015) Managed habitats increase occupancy of Black Rails Laterallus jamaicencis and may buffer impacts from sea level rise. Wetlands 36 : 1065-1076.

Roesler, I., Imberti, S., Casanas, H., Mahler, B. and Reboreda, J. C. (2012a) Hooded Grebe Podiceps gallardoi population decreased by 
eighty per cent in the last twenty-five years. Bird Conserv. Internatn. 22: 371-382.

Roesler, I., Imberti, S., Casanas, H. and Volpe, N. (2012b) A new threat for the globally Endangered Hooded Grebe Podiceps gallardoi: the American mink Neovison vison. Bird Conserv. Internatn. 22: 383-388.

Roesler, I., Imberti, S., Casañas, H., Hernández, P., Klavins, J. and Pagano, L. (2014) Noteworthy records and natural history comments on rare and threatened bird species from Santa Cruz province, Patagonia, Argentina. Revista Brasileira de Ornitologia, 22: 189-200.
Ruzzante, D. E. and Rabassa, J. (2011) Palaeogeography and palaeoclimatology of Patagonia: effects on biodiversity. Biol. J. Linn. Soc. 103: 221-228.

Taylor, B., Boesman, P., de Juana, E. and Sharpe, C. J. (2018) Austral Rail Rallus antarcticus. In: J. del Hoyo, A. Elliot, J. Sargatal, D. A. Christie and E. de Juana, eds. Handbook of the birds of the world alive. Barcelona, Spain: Lynx Edicions.

Taylor, B. and van Perlo, B. (1998) Rails: a guide to rails, crakes, gallinules and coots of the world. Robertsbridge, UK: Pica Press.

\footnotetext{
ANDRES DE MIGUEL ${ }^{1,3 *}$, LAURA FASOLA ${ }^{1,2}$, IGNACIO ROESLER ${ }^{1,3}$, LUCÍA MARTIN ${ }^{1}$, NATALIA COSSA ${ }^{1,3}$, EMILIA GIUSTI ${ }^{1,3}$

${ }^{\top}$ Programa Patagonia/Aves Argentinas y Proyecto Macá Tobiano (Aves Argentinas \& Asociación Ambiente Sur).

${ }^{2}$ Consejo Nacional de Investigaciones Científicas y Técnicas (CONICET)-Delegación Técnica Patagonia, Administración de Parques Nacionales.

3 Laboratorio de Ecología y Comportamiento Animal, Dpto. Ecología, Genética y Evolución, FCEN, Universidad de Buenos Aires. IEGEBA-CONICET.

*Author for correspondence; e-mail: andi.demiguel@gmail.com
}

Received 18 March 2018; revision accepted 6 November 2018; Published online 7 March 2019 